\title{
IMPLEMENTASI KAIDAH FIQH DALAM AKAD MUDHARBAH MUTHLAQAH SEBAGAI SOLUSI PERSELISIHAN PADA PERBANKAN SYARIAH
}

\author{
Oleh: Rachmad Risqy Kurniawan, Ph.D \\ Nadia Nur Hafizah
}

\begin{abstract}
This article discusses how the implementation of the mudharabah contract in Islamic banking practices and the position of the mudharabah contract in fiqh and the scheme of the mudharabah muthlaqah contract. The purpose of this study was to determine the position of the mudharabah contract in fiqh and the practice of the mudharabah contract in Islamic banking. The results of this study reveal that the mudharabah muthlaqah contract is a collaboration between the owner of the funds or investors (shahib al-mal / rabb al-mal / investors) namely customers and capital managers (mudharib) namely Islamic banks to conduct business on the basis of profit sharing. Mudharabah profits will be divided according to the agreement that has been agreed by both parties. If a loss occurs, the loss is borne by the owner of the capital or the customer in this case, provided that the loss is not due to the mudhorib's fault. In this case, if there is a dispute between the owner of the property and the person entrusted with the mandate regarding the property, then the words received are the words of the person entrusted with the mandate, except for those entrusted to them that violate reality and habits. Because the owner of the property has entrusted the property to him and has positioned it like himself.
\end{abstract}

Keywords: Mudharabah Principle, Mudharabah Muthlaqah, Islamic Bank.

1 Manajemen Bisnis Syariah Sekolah Tinggi Ekonomi Islam SEBI 2021 


\begin{abstract}
Abstrak
Artikel ini membahas bagaimana implementasi akad mudharabah dalam praktik perbankan syariah serta bagaimana posisi akad mudharabah dalam fiqh dan bagaimana skema akad mudharabah muthlaqah. Tujuan penelitian ini adalah untuk mengetahui kedudukan akad mudharabah dalam fiqh dan praktik akad mudharabah di perbankan syariah. Hasil penelitian ini mengungkapkan bahwa akad mudharabah muthlaqah merupakan kerjasama antara pemilik dana atau investor (shahib al-mal / rabb al-mal / investor) yaitu nasabah dan pengelola modal (mudharib) yaitu Bank Syariah untuk melakukan usaha atas dasar bagi hasil. Keuntungan mudharabah akan dibagi sesuai dengan kesepakatan yang sudah disepakati kedua belah pihak. Jika terjadi kerugian maka kerugian tersebut ditanggung oleh pemilik modal atau nasabah dalam kasus ini, dengan ketentuan jika kerugian bukan karena kesalahan mudhorib. Dalam hal ini, jika terjadi perselisihan antara pemilik harta dengan orang yang diserahi amanah berkaitan dengan harta tersebut, maka perkataan yang diterima adalah perkataan orang yang diserahi amanah kecuali yang diserahi menyalahi realita dan kebiasaan. Karena pemilik harta telah mempercayakan harta kepadanya dan telah menposisikannya seperti dirinya.
\end{abstract}

Kata kunci: Prinsip Mudharabah, Mudharabah Muthlaqah, Bank Syariah.

\title{
Pendahuluan
}

Pada hakikatnya setiap manusia dalam aktifitasnya baik yang bersifat duniawi maupun ukhrowi tidak lepas dari pada tujuan (maqoshid) dari apa yang akan ia peroleh dari aktifitas tersebut, dengan berbagai macam perbedaan dari sudut pandang manusia itu sendiri. Hal ini tidak jarang dan tidak menutup kemungkinan proses pencapaian tujuan maqoshid juga bermacam-macam.

Contoh dalam kegiatan sosial ekonomi, banyak orang yang terjebak dalam masalah ini dengan mengutamakan pemenuhan hak pribadi dan mengabaikan hak orang lain baik 
dalam bentuk individu maupun masyarakat umum, padahal Islam adalah agama yang menjadi rahmat bagi seluruh alam, mengatur seluruh tatanan kehidupan manusia agar norma-norma yang diberlakukan oleh Islam dapat memberikan solusi bagi keadilan dan kewajaran dalam hal pencapaian manusia dalam tujuan kegiatannya sehingga tidak terjadi ketimpangan sosial di antara mereka ${ }^{1}$

Dengan pesatnya perkembangan perusahaan berbasis syariah di Indonesia, peluang yang dihadapi para pelaku syariah dalam mengembangkan sumber daya masyarakat adalah sosialisasi mekanisme, transaksi dan operasional di dunia usaha. Sehingga perusahaan syariah yang ada dapat berkembang secara optimal. Hal ini menjadi tantangan bagi perusahaan syariah di Indonesia. Dimana mayoritas penduduk Indonesia beragama Islam, maka partisipasi masyarakat sangat diperlukan. Secara umum dapat dikatakan bahwa hukum syariah mensyaratkan kegiatan ekonomi yang halal, baik produk yang menjadi objeknya, cara memperolehnya maupun cara pemanfaatannya ${ }^{2}$.

Maka tidak jarang di antara kita sering menemukan ayat-ayat dalam kitab suci AlQur'an yang menganjurkan perdagangan dan perdagangan, dan Islam sangat jelas dalam menegaskan sikap bahwa tidak boleh ada halangan untuk perdagangan dan bisnis yang adil dan legal sehingga bahwa setiap orang dapat memperoleh penghasilan, menafkahi keluarga mereka dan memberi sedekah kepada yang kurang beruntung.

Secara teknis mudharabah adalah kemitraan untuk mencari keuntungan, di mana satu pihak (shahibul mal) menyediakan modal dan pihak lain (mudharib) menyediakan tenaga kerja ${ }^{3}$. Mudharabah merupakan salah satu kontrak kerjasama dalam keuangan Islam, dalam pembahasan ini mudharabah muthlaqah yaitu kerjasama yang terdiri dari dua pihak, pertama adalah pihak shahibul mal atau pemilik modal yaitu nasabah menyerahkan modal $(100 \%)$ yang kemudian mempercayakan uang kepada pihak kedua, yang disebut mudharib

\footnotetext{
${ }^{1}$ Aniyati Aniyah, R. L. MUDHARABAH.

${ }^{2}$ Andiyansari, C. N. Akad Mudharabah dalam Perspektif Fikih. Jurnal Pendidikan dan Agama Islam, Hal. 42.

${ }^{3}$ ISRA. (2015). Sistem Keuangan Islam Prinsip \& Oprasional. Rajawali Pers.
} 
(pemilik usaha atau tenaga kerja) yaitu Bank Syariah untuk kemudian dikelola modal tersebut menjadi usaha yang menghasilkan laba. Beberapa ulama fiqh seperti ulama Hanafi dan Hambali menggunakan istilah mudharabah sedangkan ulama Maliki dan Syafi'i menggunakan istilah qiradh.

Prinsip mudharabah merupakan bagian dari produk perbankan syariah yang unik, karena merupakan perbedaan filosofis antara sistem perbankan konvensional dan perbankan syariah yang menganut prinsip untung atau rugi ${ }^{4}$. Prinsip bagi hasil dikenal dengan profit and loss sharing, dimana ketika mudharib mendapatkan hasil dari pengembangan modal usaha dari shaibul mal maka keuntungan yang didapat dibagi sesuai dengan perjanjian atau kesepakatan. Konsep inilah yang digagas oleh Bank Syariah bahwasannya mudharabah ini menerapkan sistem kerjasama berbasis keadilan.

\section{Rumusan Masalah}

Bagaimana praktek akad mudharabah muthlaqah dalam perbankan syariah dan apa kaidah yang mengatur masalah jika terjadi perselisihan dalam akad mudharabah?

\section{Tujuan Penelitian}

Untuk mengetahui bagaimana praktek akad mudharabah muthlaqah dalam perbankan syariah dan mengetahui kaidah yang mengatur jika terjadi masalah perselisihan dalam akad mudharabah.

\section{Pembahasan}

\section{Praktik Akad Mudharabah Muthlaqah dalam Perbankan Syariah}

\footnotetext{
${ }^{4}$ Ibrahim, K. (April 2014). Penerapan Prinsip Mudharabah Dalam Perbankan Syariah. Jurnal ius Vol II, Hal. 42
} 
Mudharabah merupakan salah satu kontrak kerjasama yang menjunjung asas keadilan sesuai dengat syariat Islam. Mudharabah merupakan kerjasama antara dua belah pihak yakni shahibul mal yaitu nasabah dengan mudharib yaitu pihak Bank Syariah, di mana nasabah sebagai pemilik modal mempercayakan kepada pihak Bank Syariah sebagai mudharib yang selanjutnya akan dikembangkan menjadi sebuah usaha tertentu. Penyertaan modal disertai dengan berbagai perjanjian tentang bagi hasil yang telah disepakati bersama dengan landasan profit and loss sharing.

\begin{tabular}{|c|c|c|c|}
\hline & \multicolumn{3}{|c|}{ BSI TABUNGAN EASY MUDHARABAH } \\
\hline Akad & \multicolumn{3}{|c|}{$\begin{array}{l}\text { Mudharabah Muthlaqah: nasabah bertindak sebagai pemilik } \\
\text { dana dan bank sebagai pengelola dana }\end{array}$} \\
\hline \multirow{4}{*}{ Bagi Hasil/Bonus } & saldo & nasabah & bank \\
\hline & $<\mathrm{Rp} 100$ Juta & $8 \%$ & $92 \%$ \\
\hline & $\geq R p 100$ Juta & $13 \%$ & $87 \%$ \\
\hline & \multicolumn{3}{|c|}{ * Jika ada perubahan porsi nisbah akan diinformasikan minimal 30 hari kerj } \\
\hline Biaya Administrasi & \multicolumn{3}{|c|}{ Rp. $10.000,-$ per bulan } \\
\hline Setoran Awal & \multicolumn{3}{|c|}{ Rp. $100.000,-$} \\
\hline Saldo Minimal & \multicolumn{3}{|c|}{ Rp. $50.000,-$} \\
\hline Biaya Tutup Rekening & \multicolumn{3}{|c|}{ Rp. $20.000,-$} \\
\hline Biaya Dormant/Bulan & \multicolumn{3}{|c|}{ Rp. 5.000,- } \\
\hline
\end{tabular}

Gambar 1 skema akad mudharabah muthlaqah di BSI ${ }^{5}$

Prinsip dasar yang diterapkan oleh bank syariah dalam hal pengelolaan dana adalah bahwa bank syariah harus dapat membagi keuntungan dengan penyimpan dana minimal sama atau lebih besar dari tarif bunga yang berlaku di bank konvensional, dan mampu menarik bagi hasil dari debitur lebih rendah dari bunga yang ada di bank konvensional ${ }^{6}$.

Kontrak mudharabah diterbitkan oleh bank syariah sebagai salah satu kontrak kemitraan keuangan syariah. Akad mudharabah terdapat dalam undang-undang perbankan syariah nomor 21 tahun 2008, pasal 19 huruf (b) dan huruf (c) Tentang Perbankan Syariah, dimana akad mudharabah adalah akad yang digunakan oleh bank syariah dan LKS untuk

${ }^{5}$ (2021). Diambil kembali dari https://webform.bsm.co.id/catalog/keterangan/1

${ }^{6}$ Prasetyanti, S. d. (September 2011). Jurnal Keuangan dan Pendidikan, Hal. 468. 
menghimpun dana dalam bentuk investasi dalam bentuk deposito, tabungan atau bentuk lainnya. Selain penghimpun dana, akad mudharbah juga merupakan akad penyaluran dana berupa pembiayaan dengan bagi hasil ${ }^{7}$.

Aplikasi dalam perbankan, pada sisi penghimpunan dana, mudharabah diterapkan pada: A. Tabungan berjangka, yaitu tabungan yang dimaksudkan untuk tujuan khusus, seperti tabungan haji, tabungan kurban, dan sebagainya. B. Deposito spesial (special invesment), dimana dana yang dititipkan nasabah khusus untuk bisnis tertentu ${ }^{8}$.

Sesuai dengan penjelasan undang-undang yang telah diatur, akad mudharabah merupakan akad antara pihak pertama (rabbul mal, shaihbul mal, nasabah) yang menyediakan seluruh modal dan pihak kedua (amil, mudharib, Bank Syariah, LKS) selaku pengelola dana yang membagi keuntungan sesuai kesepakatan. Sedangkan kerugian ditanggung oleh shahibul mal kecuali pihak kedua melakukan kelalaian atau kesalahan yang disengaja atau pun tidak mematuhi perjanjian yang ada.

Pembagian keuntungan yaitu jumlah yang didapat sebagai kelebihan dari modal antara shahibul mal dengan mudharib juga harus memenuhi syarat-syarat sebagai berikut":

a. Pembagian keuntungan dinyatakan dalam prosentase/ proporsi dari hasil keuntungan.

b. Bagi hasil masing-masing pihak harus diketahui dan ditunjukkan pada saat akad dan disepakati dalam prosentase/proporsi (harus menyepakati perubahan nisbah).

c. Pembagian hasil keuntungan dapat dibagikan setelah pengelola mengembalikan sebagian atau seluruh modalnya kepada pemilik modal.

\footnotetext{
${ }^{7}$ Ibrahim, K. (April 2014). Penerapan Prinsip Mudharabah Dalam Perbankan Syariah. Jurnal ius Vol II, Hal. 42

${ }^{8}$ Muhammad Syafi'i Antonio (2011). Bank Syariah: Dari Teori ke Praktik. Jakarta: Gema Insani.

${ }^{9}$ Muhammad, Sistem dan Prosedur Operasional Bank Syariah, Yogyakarta: UII Press, 2000, Hal. 16-17
} 
Dalam diktum ketiga Fatwa DSN MUI No. 07/DSN-MUI/IV/2000 tentang beberapa ketentuan hukum pembiayaan mudharabah (qiradh) menyebutkan sebagai berikut ${ }^{10}$ :

1) Mudharabah dapat dibatasi untuk jangka waktu tertentu.

2) Kontrak tidak terkait (mu`allaq) dengan peristiwa masa depan yang belum tentu benar.

3) Dalam mudharabah, tidak ada ganti rugi karena akad pada hakikatnya adalah amanah (yad al-amanah), kecuali karena kesalahan yang disengaja, kelalaian atau pelanggaran perjanjian.

4) Jika salah satu pihak gagal melaksanakan kewajibannya atau terjadi perselisihan antara kedua belah pihak, penyelesaian dilakukan melalui arbitrase Syariah setelah musyawarah dan tidak tercapainya kesepakatan.

Macam-macam risiko yang mungkin terjadi dan menimbulkan perselisihan pada pola bank sebagai penghimpunan dana yaitu, akibat tersedianya produk giro/tabungan/deposito dalam denominasi valuta asing, hal ini bisa memunculkan risiko pasar akibat fluktuasi nilai tukar. Selanjutnya, risiko likuiditas, risiko ini berpotensi muncul ketika nasabah membutuhkan likuiditas sedangkan bank tidak mampu memenuhi kebutuhan akan permintaan tersebut. Bank juga berpotensi mengalami risiko operasional akibat adanya kesalahan manusiawi (human error), ketidakcukupan atau tidak berfungsinya proses internal, kegagalan sistem atau adanya problem eksternal yang berpengaruh terhadap kegiatan operasional bank.

Risiko reputasi muncul akibat adanya perspektif negatif terhadap bank yang akhirnya menurunkan tingkat kepercayaan masyarakat terhadap bank. Selanjutnya, risiko strategi berpotensi dimiliki setiap bank karena risiko ini berhubungan dengan kemampuan manajemen dalam merumuskan strategi sampai dengan melakukan analisis terhadap lingkungan internal dan eksternal entitas bisnis. Risiko kepatuhan terjadi ketika bank

\footnotetext{
${ }^{10}$ Fatwa Dewan Syariah Nasional MUI N0. 07/DSN-MUI/IV/2000
} 
melanggar peraturan ataupun ketentuan dan prinsip syariah yang berlaku. Dalam pola penghimpunan, risiko bagi hasil muncul akibat adanya perbedaan antara bagi hasil yang diterima dengan bagi hasil yang diharapkan nasabah yang berakibat pada perubahan perilaku nasabah dalam menyimpan dananya. Sementara itu, risiko investasi tidak berpotensi muncul karena bank tidak menanggung kerugian atas investasi sebab kerugian ditanggung oleh nasabah selaku shahibul mal ${ }^{11}$.

\section{Implementasi Kaidah Fiqh Sebagai Solusi Perselisihan dalam Akad Mudharabah}

Terkadang terjadi perselisihan antara pemilik harta dan orang yang diamanahkan atau pengelola modal untuk mengelola harta yang diamanahkan, akibat risiko-risiko yang mungkin terjadi terutama risiko operasional, kaidah fiqh yang membahas jika terjadi perselisihan kedua belah pihak yaitu:

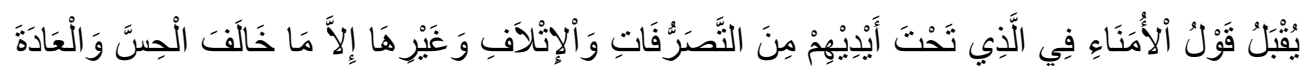

"Perkataan orang yang diserahi amanah berkaitan dengan pengelolaan, kerusakan dan masalah lain yang berhubungan dengan harta yang diamanahkan kepadanya diterima, kecuali apabila menyelisihi realita dan kebiasaan"12.

Kaidah ini sangat penting untuk menyelesaikan perselisihan antara pemilik harta dan orang yang diserahi amanah untuk mengelola harta tersebut. Dalam akad mudharabah atau yang semisalnya, pemilik harta (pemodal) yaitu nasabah mempercayakan hartanya kepada pihak yang diserahi amanah yaitu Bank Syariah untuk di kelola, baik dalam perdagangan, sewa atau lain sebagainya. Perkataan orang yang diserahi amanah meliputi pengelolaan, kerusakan dan masalah lain yang berhubungan dengan harta tersebut maka perkataannya diterima. Namun, apabila pernyataan orang yang diserahi amanah tersebut

\footnotetext{
${ }^{11}$ Lusiana Watiningsih, ANALISIS RISIKO TRANSAKSI AKAD MUDHARABAH. Hal. 9-10

12 (2010). Diambil kembali dari Al- Manhaj: https://almanhaj.or.id/3591-kaidah-ke-26-jika-terjadiperselisihan.html
} 
menyelisihi kebiasaan atau tidak selaras dengan realita yang ada, maka pernyataannya tidak diterima ${ }^{13}$.

Prinsip perbankan syariah adalah bagi hasil, sehingga dilakukan atas dasar kesepakatan kedua belah pihak. Salah satu prinsip bisnis perbankan syariah adalah akad bagi hasil dan risiko, dimana bank dan nasabah berbagi keuntungan berdasarkan nisbah bagi hasil yang telah ditentukan. Jika salah satu pihak tidak menunaikan kewajibannya maka sebaiknya dimusyawarahkan. Bila tidak dapat dimusyawarahkan dengan baik maka selanjutnya dapat diselesaikan melalui dua cara, yakni penyelesaian secara litigasi (peradilan) yaitu ke badan hukum melalui pengadilan dalam lingkungan Peradilan Umum yang dilakukan di Pengadilan Agama dan tidak boleh bertentangan dengan prinsip syariah. Dan non litigasi (non-peradilan) yaitu penyelesaiannya berdasarkan itikad baik yang dimiliki para pihak yang bersengketa bisa melalui Arbitrase dan Alternatif Penyelesaian Sengketa (APS).

Sebagaimana yang dijelaskan dalam kaidah, jelas bahwa jika terjadi kerugian maka yang diterima adalah perkataan pengelola modal atau dalam pembahasan ini adalah Bank Syariah dan pemilik modal yaitu nasabah siap menanggung kerugian, namun, jika kerugian diakibatkan kesengajaan, kelalaian, atau menyimpang dari realitas maka pernyataan pengelola modal (mudharib) tidak diterima dan dapat diselesaikan dengan musyawarah. Jika musyawarah tidak tercapai maka dapat diselesaikan dengan cara litigasi dan nonlitigasi. Litigasi berarti membawa permasalahan sengketa ke jalur hukum sedangkan proses non litigasi penyelesaiannya berdasarkan itikad baik yang dimiliki para pihak yang bersengketa atau berselisih.

\section{Kesimpulan}

Mudharabah merupakan salah satu kontrak kerjasama dalam keuangan Islam, dalam hal ini kerjasama yang terdiri dari dua pihak yang pertama pihak pemilik moal yaitu

\footnotetext{
${ }^{13}$ (2010). Diambil kembali dari Al- Manhaj: https://almanhaj.or.id/3591-kaidah-ke-26-jika-terjadiperselisihan.html
} 
nasabah menyediakan modal (100\%) yang kemudian mempercayakan uang kepada pihak Bank Syariah, yang disebut mudharib untuk kemudian mengelola modal tersebut menjadi usaha yang menghasilkan laba.

Prinsip perbankan syariah adalah bagi hasil sehingga hal ini dilakukan didasarkan pada kesepakatan yang dibuat oleh kedua belah pihak. Salah satu prinsip usaha Perbankan Syariah adalah akad bagi hasil dan risiko dimana bank dan nasabah membagi keuntungan berdasarkan rasio bagi hasil yang ditentukan sebelumnya. Jika terjadi perselisihan antar kedua belah pihak sebab beberapa risiko yang mungkin terjadi, sebagaimana dalam kaidah fiqh yang membahas jika terjadi perselisihan antara pemilik modal dan pengelola maka perkataan yang dapat dipercaya dan diterima adalah perkataan pengelola dalam hal ini adalah Bank selama hal itu tidak menyimpang dari realitas dan kebiasaan. Hal ini dapat dimusyawarahkan terlebih dahulu sebelum di bawa ke pihak berwenang. Bila tidak dapat dimusyawarahkan dengan baik maka selanjutnya dapat diselesaikan melalui dua cara, yakni penyelesaian secara litigasi (peradilan) yaitu ke badan hukum melalui pengadilan dalam lingkungan Peradilan Umum yang dilakukan di Pengadilan Agama dan tidak boleh bertentangan dengan prinsip syariah. Dan non litigasi (non-peradilan) yaitu penyelesaiannya berdasarkan itikad baik yang dimiliki para pihak yang bersengketa bisa melalui arbitrase dan Alternatif Penyelesaian Sengketa (APS).

\section{Daftar Pustaka}

(2010). Diambil kembali dari Al- Manhaj: https://almanhaj.or.id/3591-kaidah-ke-26-jikaterjadi-perselisihan.html

(2021). Diambil kembali dari https://webform.bsm.co.id/catalog/keterangan/1

Andiyansari, C. N. (t.thn.). Akad Mudharabah dalam Perspektif Fikih. Jurnal Pendidikan dan Agama Islam, 42. 
Aniyati Aniyah, R. L. (t.thn.). MUDHARABAH.

Eprianti, S. d. (April 2017). Penerapan Prinsip Keadilan Dalam Akad Mudharabah Di Lembaga Keuangan Syariah. Jurnal Law and Justice Vol.2 No.1, 7.

Fatwa Dewan Syariah Nasional MUI N0. 07/DSN-MUI/IV/2000

Ibrahim, K. (April 2014). Penerapan Prinsip Mudharabah Dalam Perbankan Syariah. Jurnal ius Vol II, 42.

ISRA. (2015). Sistem Keuangan Islam Prinsip \& Oprasional. Rajawali Pers.

Lusiana Watiningsih, ANALISIS RISIKO TRANSAKSI AKAD MUDHARABAH. Hal. 9-10

Mudharabah Dalam Fiqih Dan Perbankan Syariah. ( Desember 2013). JURNAL equilibrium, 304.

Muhammad, Sistem dan Prosedur Operasional Bank Syariah, Yogyakarta: UII Press, 2000, Hal. 16-17

Muhammad Syafii Antonio (2011). Bank Syariah: Dari Teori ke Praktik. Jakarta: Gema Insani.

Prasetyanti, S. d. (September 2011). Jurnal Keuangan dan Pendidikan, 468. 